\title{
The EFFeCt OF The STRATEgY OF Finishing ON DIMENSIONAL ACCURACY
}

\author{
Luboš Kroft*, Jan Hnatík \& Kateřina Bícová
}
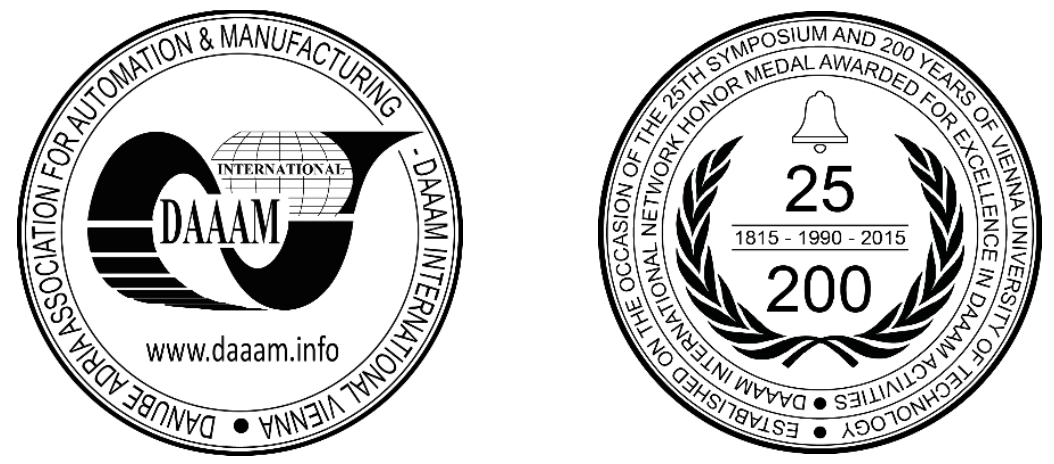

This Publication has to be referred as: Kroft, L[ubos]; Hnatík, J[an] \& Bicova, K[aterina] (2017). The Effect of The Strategy of Finishing on Dimensional Accuracy, Proceedings of the 28th DAAAM International Symposium, pp.05750581, B. Katalinic (Ed.), Published by DAAAM International, ISBN 978-3-902734-11-2, ISSN 1726-9679, Vienna, Austria

DOI: $10.2507 / 28$ th.daaam.proceedings.081

\begin{abstract}
The trend of today is to manufacture even highly-intricate parts in the least number of technological steps. With this strategy, it is necessary to finish complex 3D surfaces with the best qualitative results. Where mill finishing is the last operation (e.g. in making a forging die), it is essential that the quality of the finished surface is acceptable without the need for other finishing technologies. This paper deals with the influence of the chosen finishing strategy on dimensional accuracy. In many types of production, dimensional accuracy is more fundamental than, for example, the quality of the finished surface. Also, efforts to meet very narrow tolerance limits for complex 3D surfaces with milling are becoming more and more common. Another aspect analysed here is the use of constant cutting speed in mill finishing with the aim to increase the efficiency of finishing operations.
\end{abstract}

Keywords: Machining; Finishing operations; Constant cutting speed; Qualitative results; Strategy

\section{Introduction}

Operations planning is being increasingly dominated by CA (computer-aided) systems. Advanced CAD/CAM systems offer a number of functionalities with a broad range of operations and upgrades which contribute to machining quality. [6] Their strengths are best manifested in tasks that involve complex tool paths. Such paths, which are typically used in machining three-dimensional intricate-shaped surfaces, are mostly associated with milling.

Milling has seen major developments in the recent decade. A majority of innovation efforts, whether involving improvement in the cutting performance of tools or upgrading the functional properties of machines and clamping equipment, aim to enhance the productivity and reduce the production costs of milled surfaces.CAM systems and their milling strategies are a potent tool for increasing the efficiency of preparation of both NC programs and the actual production. This applies particularly to roughing and semi-finishing strategies. 
CAM systems offer superior solutions for these machining stages. The main reasons are the adaptive control of the tool and the growing use of trochoidal tool path generation. As a result, near-constant tool loads can be achieved. More aggressive cutting conditions can be applied with these strategies to improve productivity.

This article describes an investigation which focused on the finishing stage. The finishing strategies available in today's CAM systems are relatively powerful and of reasonable quality. One disadvantage is that tools for aggressive cutting conditions are not available for finishing strategies, unlike in the previous two stages.

Today, efficiency can only be improved by selecting a different machine, cutting tool, clamping method or by other alterations to the machine-tool-workpiece-fixture system. Finishing thus becomes rather time-consuming and costly, particularly with intricate-shaped surfaces.

Several scientific studies were therefore devoted to investigating the potential for improving the finishing efficiency. An example of how finishing strategies compare is presented in [10]. The paper compared finishing strategies in 5-axis operations but mainly from the productivity perspective.

More interesting information can be found in article [11] which dealt with machined surface accuracy but only in terms of interpolation of the surface and not as a result of a particular strategy.

Nevertheless, there are studies which are closer to the issue of our interest. The paper "The Influence of Different Types of Copy Milling on the Surface Roughness and Tool Life of End Mills" [7] focused on the impact of the finishing strategy on tool wear and on the dimensional accuracy of the finished surface.

In terms of certain parameters, these studies correspond with the topic discussed here. However, none of them explores the relationship between a machining strategy and the use of a constant cutting speed, the dimensional accuracy, and the geometric accuracy of the finished surface. The purpose of this article is to present the current results of research into these aspects.

\begin{tabular}{|ll|}
\hline CA & Computer Aided \\
CAM & Computer Aided Manufacturing \\
CAD & Computer Aided Design \\
CNC & Computer Numerical Control \\
CMM & Coordinate-measuring machine \\
$Z$ & Linear Z axis \\
$a_{p}$ & Stepover \\
$f_{z}$ & Feed per tooth \\
$v_{c}$ & Cutting Speed \\
$D_{\mathrm{DIN}}$ & Deutsche Industrie-Norm (German Industrial Standard) \\
$D_{\text {tool }}$ & Tool diameter \\
\hline
\end{tabular}

Table 1. Symbols

\section{Finishing strategy}

The key distinction between finishing operations and roughing and semi-finishing is in the requirement for achieving specified dimensional accuracy and quality of surface, ideally within the shortest time. These requirements are reflected in the operations offered by CAM systems.

In finishing, the main difference is in the choice between parallel machining and flow-line machining. For illustration, Figure 1 shows the results of the research report presented in [9] which covered this topic. They clearly indicate that the choice of strategy has an impact on the dimensional accuracy of the finished surface. [8] 
A)

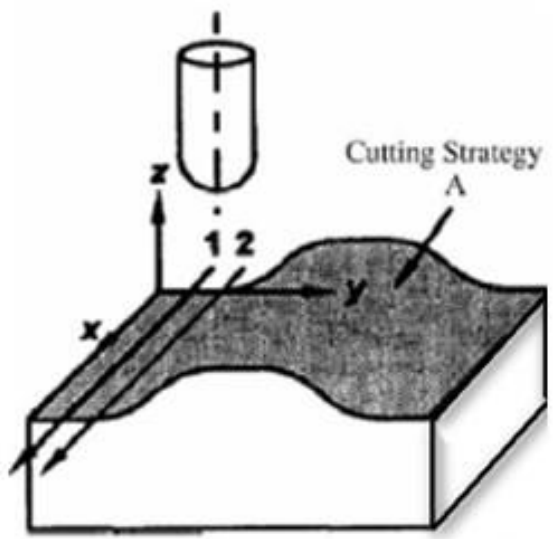

C)

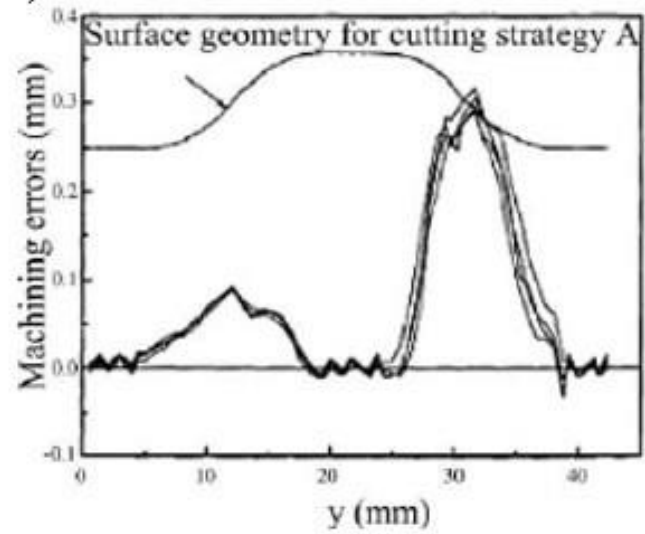

B)

D)
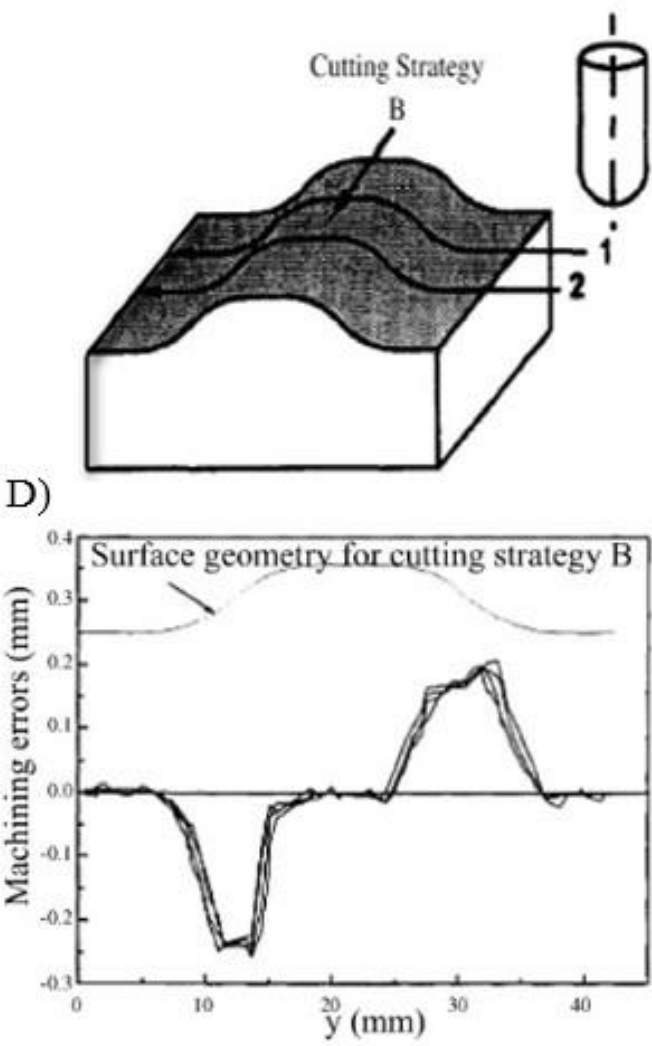

Fig. 1. Examples of stepover calculation strategies: A) Parallel machining strategy, B) Flow-line machining strategy, C) Results of parallel machining strategy, D) Results of flow-line machining strategy. [9]

However, this research did not deal with curve-based stepover calculation, and therefore it was not quite clear whether this parameter had an impact on the finished surface.

\begin{tabular}{|c|c|c|c|c|c|c|c|}
\hline $\begin{array}{l}\text { Machining } \\
\text { methods }\end{array}$ & $\begin{array}{c}\mathrm{NC} \\
{[\mathrm{KB}]}\end{array}$ & $\begin{array}{c}\text { Simulation } \\
\text { diagram }\end{array}$ & $\begin{array}{c}\text { Feed Path } \\
\text { Length [mm] }\end{array}$ & $\begin{array}{c}\text { Rapid Path } \\
\text { Length [mm] }\end{array}$ & Cycle Time & Efficiency & quality \\
\hline Parallel & 515.8 & 3-a & 2539.828 & 454.349 & $5 \mathrm{~m} 43.68 \mathrm{~s}$ & (3) & great \\
\hline Flowline & 258.8 & 3-b & 2127.253 & 17.000 & $4 \mathrm{~m} 43.83 \mathrm{~s}$ & (1) & perfect \\
\hline Contour & 517.6 & $3-d$ & 2095.197 & 820.479 & $4 \mathrm{~m} 48.43 \mathrm{~s}$ & (2) & bad \\
\hline $\begin{array}{l}\text { Constant } \\
\text { Scallop } \\
\text { Constant }\end{array}$ & 742.4 & $3-e$ & 1703.711 & 63.03 & $3 \mathrm{~m} 47.69 \mathrm{~s}$ & 1 & worst \\
\hline $\begin{array}{l}\text { Scallop\&Sh } \\
\text { allow }\end{array}$ & 1131.7 & 3-f & 2640.632 & 941.057 & $6 \mathrm{~m} 00.01 \mathrm{~s}$ & (4) & good \\
\hline
\end{tabular}

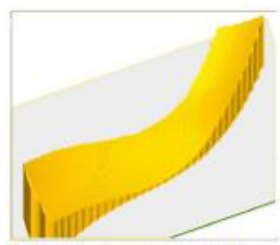

(a) Finish Parallel

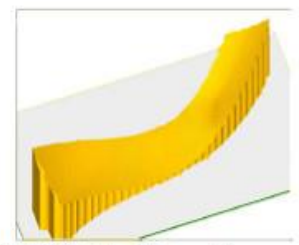

(b) Finish Flow-line

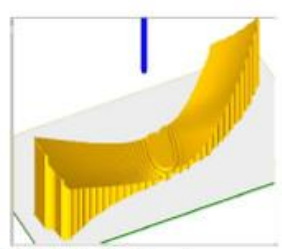

(c) Finish Contour

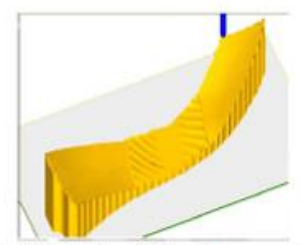

(e)Constant Scallop

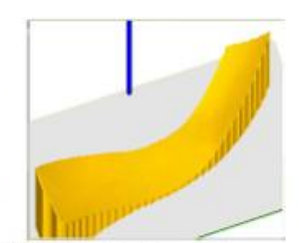

(f) Constant

Fig. 2. Comparison between strategies applied to a shaped surface [3]

The topic is, however, described in the article "Tool-Path Scheduling for Free-Form Surface Based on MasterCAM" [3]. This study focused on the effects of stepover calculation but not on the impact on the accuracy of the finished surface, see Fig. 2. Nevertheless, it was clear that the type of stepover calculation had a fundamental bearing on the quality of the finished surface. In finishing of shaped surfaces, the choice of strategy is one of important aspects. 


\subsection{Role of rough-machined surface in the choice of finishing strategy}

Dimensional accuracy, however, depends on many other variables and factors as well. One of them is the preceding manufacturing operation. There are smooth transitions between various parts of 3D surfaces, exhibiting different slopes and characters, depending on the surface complexity. The uniformity of semi-finished surface is manifested in the variation of the volume removed by the finishing tool. This is why the parameter represented by the distance between roughing or semi-finishing passes is so important, as shown in Fig. 3

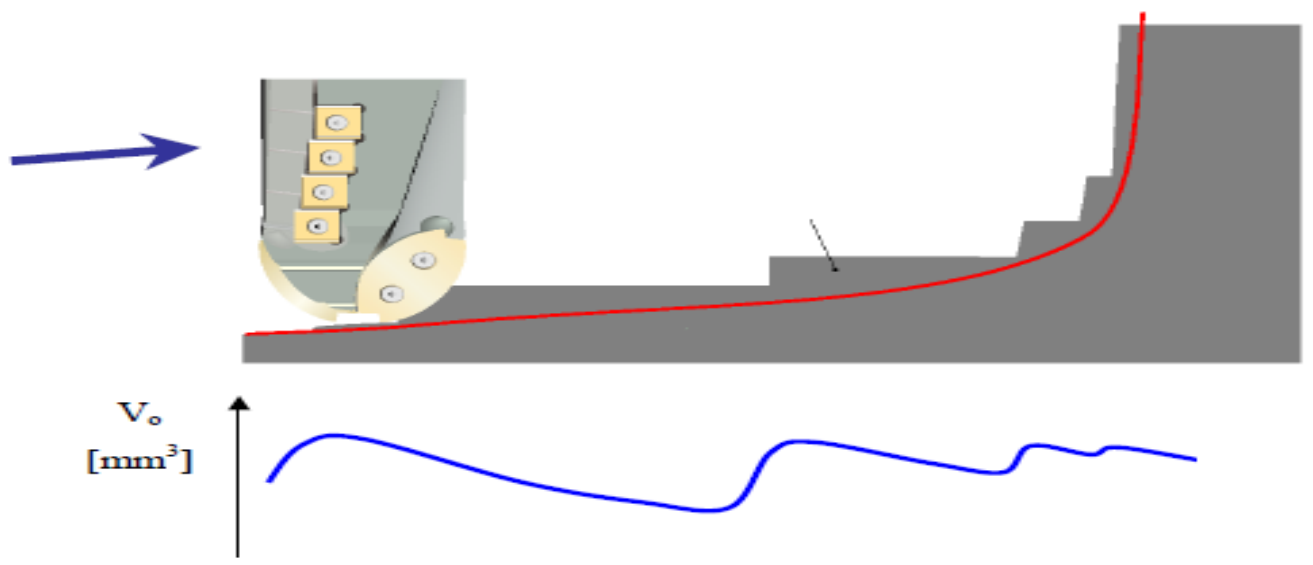

Fig. 3. Plot of volume removed profile [2]

This fact is well-known. Despite that, variation in the volume removed in finishing operations are, to a great extent, unavoidable. At the same time, the roughing stepover and/or semi-finishing stepover should be chosen with respect to the cutting process stability. Variation in the volume removed can lead to instabilities in the cutting process, as reflected, for instance, in the cutting force profile. Where cutting forces steeply increase, undesirable consequences may occur, such as out-of-tolerance and poor-quality finished surface and others.

These consequences can be addressed in several ways. One of them involves improved quality of semi-finished surface. However, that entails longer machining times, and therefore lower efficiency. Another one is based on using finishing tool paths with variable feed rates. This reduces cutting force fluctuations and improves the stability of the cutting process. [2, 4] The third option is to make finishing operations similar to adaptive roughing. The algorithm would evaluate the volume removed and if a certain limit was exceeded, it would generate such paths which prevent tool vibration.

\section{Testing - effect of the choice of finishing strategy upon dimensional accuracy of finished surface}

The purpose of finishing is to impart the workpiece its final form as specified on drawings. Besides the machined surface quality, another fundamental aspect is the dimensional accuracy of the finished surface. Dimensional accuracy is governed by numerous factors, including machine-tool stiffness, cutting tool type, workpiece clamping method and cutting conditions. $[1,5]$

As the above sections demonstrate, the finishing strategy has a major impact on dimensional accuracy. For this reason, an experiment was designed in which curve-based stepover calculation is analysed, namely constant $\mathrm{Z}$ stepover calculation and constant stepover calculation along a curve. Furthermore, differences arising from the use of constant cutting speed and constant rotation speed were examined. The choice of constant rotation speed in cutting enables productivity for finishing operations to be increased.

\subsection{Choice of test part}

An experimental part was designed, as shown in Fig. 4. The part has several flat surfaces which slope at angles from $0^{\circ}$ to $90^{\circ}$. It is a representation of a shaped surface and is suitable for straightforward evaluation of roughness and verification of dimensional accuracy. [1]

\begin{tabular}{|l|c|}
\hline \multicolumn{2}{|c|}{ Experimental part } \\
\hline Material [W.Nr.] & $\mathrm{C} 45$ \\
\hline Workpiece dimensions [mm] & $60 \times 90 \times 100$ \\
\hline Slope angles & $0^{\circ}, 15^{\circ}, 30^{\circ}, 45^{\circ}, 60^{\circ}, 75^{\circ}, 90^{\circ}$ \\
\hline
\end{tabular}

Table 2. Details of the experimental part 
Details of the workpiece dimensions are given in Table 2.

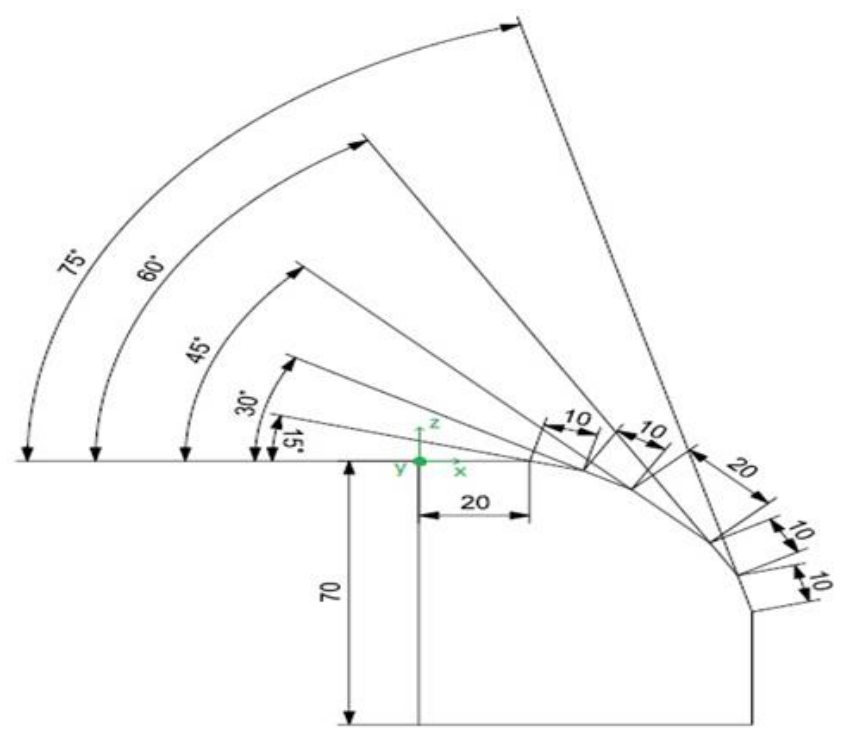

Fig. 4. Tested shaped surface [1]

\subsection{Tool selection}

A ball end mill was employed, which is used predominantly for finishing sculptured 3D surfaces. With such tools, the effective cutting diameter changes with the slope of the original surface. Therefore, the effective cutting speed varies when standard strategies are used in which rotation speed is based on the maximum diameter of the tool.

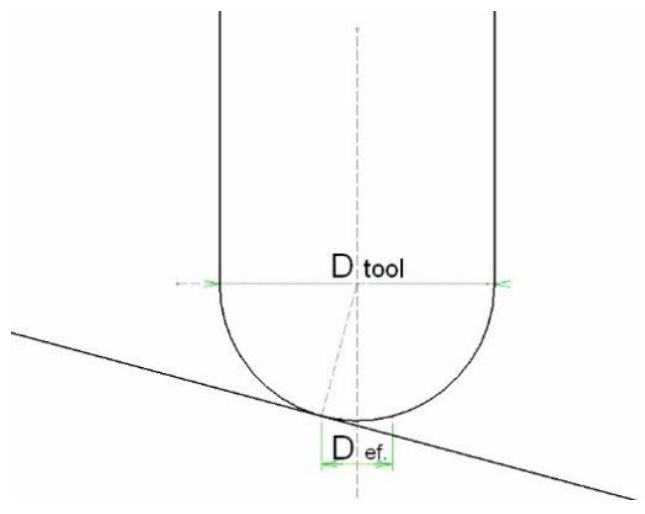

Fig. 5. Effective cutting diameter in cutting a sloping surface

\begin{tabular}{|l|c|}
\hline \multicolumn{2}{|c|}{ Tool } \\
\hline Supplier & ISCAR \\
\hline Designation & HCM D16-A-L130-C16 \\
\hline$D_{\text {tool }}[\mathrm{mm}]$ & 16 \\
\hline Number of teeth & 2 \\
\hline & \\
\hline $\mathrm{v}_{\mathrm{c}}[\mathrm{m} / \mathrm{min}]$ & Cutting conditions \\
\hline $\mathrm{a}_{\mathrm{p}}[\mathrm{mm}]$ & \\
\hline $\mathrm{f}_{\mathrm{z}}[\mathrm{mm}]$ & 150 \\
\hline
\end{tabular}

Table 3. Tool and cutting conditions

\subsection{Choice of strategy}

In order to verify the assumptions, two tool path stepover calculation strategies were chosen:

- constant Z

- curve-based constant stepover calculation 
Both strategies were implemented by manual programming. Therefore, any potential influence of a CAM system was eliminated and accurate stepover calculation for the tool path was obtained. Details of the experiment are given in Tables 3 and 4.

\begin{tabular}{|c|l|}
\hline Cubes & Strategy \\
\hline 1 & Stepover calculation along a curve - constant $\mathrm{n}$ \\
\hline 2 & Constant $\mathrm{Z}$ stepover calculation - constant $\mathrm{n}$ \\
\hline 3 & Stepover calculation along a curve - constant $\mathrm{vc}$ \\
\hline 4 & Constant $\mathrm{Z}$ stepover calculation - constant $\mathrm{vc}$ \\
\hline
\end{tabular}

Table 4. Strategies chosen for individual cubes

Cutting forces were measured using a Kistler load cell. Dimensional accuracy was evaluated using a CMM instrument (Carl Zeiss Prismo 7 Navigator).

\section{Evaluation of the experiment}

In order to obtain objective data on dimensional accuracy, readings along three section planes were collected from each surface under test. This translates into 9 points for each surface under test. This is sufficient for subsequent evaluation. A mean value was calculated from these readings. Hence, seven values were obtained for each cube, i.e. one value for each machined surface.

The mean values from measured data for individual surfaces are plotted in the graphs. The graphs show that the total variance in cubes 2 and 4 is smaller than in cubes 1 a 3 .

In cubes 1 and 3, the amount of rest material above the nominal surface increases uniformly up to the 4th surface, beyond which it decreases uniformly. By contrast, the amount of rest material above the nominal surface varies considerably in cubes 2 and 4 .

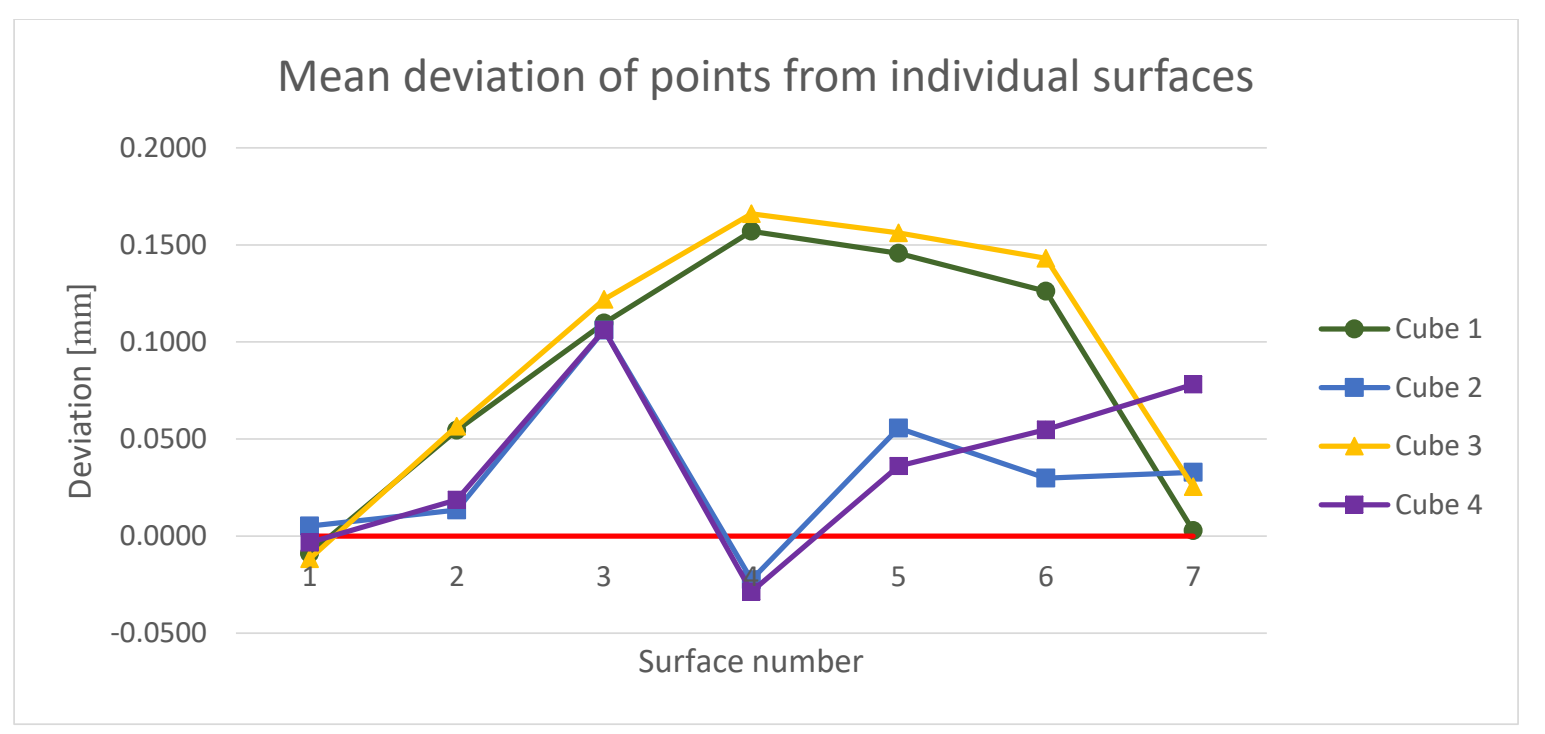

Graph 1. Average distance of points from individual surfaces

The cutting force values indicate that using a constant cutting speed can reduce the interval of cutting forces by up to several tens of newton's [N]. This is a relatively significant advantage from the perspective of finishing, where the maximal cutting forces are not of key importance because the purpose is to machine the surface as uniformly as possible.

\begin{tabular}{|l|c|c|}
\hline \multicolumn{1}{|c|}{ Strategy } & Cutting force interval [N] & $\begin{array}{c}\text { Machine time for machining } \\
\text { [min] }\end{array}$ \\
\hline Stepover calculation along a curve - constant n & 48.439 & 77 \\
\hline Constant Z stepover calculation - constant n & 65.16 & 67 \\
\hline Stepover calculation along a curve - constant vc & 28.85 & 47 \\
\hline Constant Z stepover calculation - constant vc & 54.401 & 44 \\
\hline
\end{tabular}

Table 5. Cutting force values and machining times for individual strategies 


\section{Summary}

The measured data show that from the perspective of dimensional accuracy of the finished surface, the choice of strategy or tool path stepover calculation has a relatively significant impact. Both strategies used here, however, result in considerable deviations from the nominal surface. The research team considers the stepover calculation along a curve to be more favourable. This stepover calculation exhibits a uniform increase in the amount of rest material. In addition, it is easier to meet the prescribed dimensional tolerance with the stepover calculation along a curve. Better inaccuracy compensation is achieved with this strategy than with the other one where the profile varies considerably.

The use of constant cutting speed leads to a narrower interval of measured cutting forces. In addition, machining times are significantly shorter at constant cutting speed. One can therefore conclude that this option improves the efficiency of finishing.

The findings provide insight into the effects of finishing strategies which can lead to shorter machining times, better surface and, last but not least, control over dimensional accuracy. This article describes a pre-experiment which can be useful for developing a relevant methodology. The research team continues to explore this issue. Over a long term, further relationships between the parameters of finishing of shaped surfaces will be explored. On this basis, a methodology could be developed in future to simplify the choice of finishing parameters for specific requirements.

\section{Acknowledgments}

This paper includes results created within the SGS-2016-005: Research and development for innovations in the field of mechanical engineering technology - machining technology.

\section{References}

[1] Andrlik, J[iří]. (2017). Návrh strategie dokončování tvarových ploch - Draft of the strategy for the finishing contoured surfaces. Plzeň,. Diplomová práce. Západočeská univerzita v Plzni.

[2] Sova, F.; Hamouz, L. (2014). Softwarová optimalizace dráhy frézovacího nástroje při práci na čisto - Software optimization of the trajectory of the milling tool at work to finishing. In Strojírenská technologie - Plzeň. Plzeň: Západočeská univerzita. s. 1-15. ISBN: 80-7043-304-3

[3] Ren, W. J.; He, J. Y.; Yu, Y. (2014). Tool-Path Scheduling for Free-Form Surface Based on MasterCAM, Applied Mechanics and Materials, Vols. 556-562, pp. 1400-1403, Available from: https://www.scientific.net/AMM.556562.1400

[4] Zuperl U.; Cus F.; Reibenschuh M. (2010). Neural control strategy of constant cutting force system in end milling [online]. [cit. 2017-5-29]. Available from: http://www.sciencedirect.com/science/article/pii/S0736584510001468

[5] Czerech, Ł[ukasz].(2013). Selection of Optimal Machining Strategy in the Manufacture of Elements Bounded by Curvilinear Surfaces. acta mechanica et automatica, 7.1: 5-10. Available from: http://www.degruyter.com/view/j/ama.2013.7.issue-1/ama-2013-0001/ama-2013-0001.xmla

[6] Sadílek, M. (2004). Vyspělé strategie ve 3D frézování - Advanced strategies in 3D milling. MM Spektrum. [online]., [cit. 2017-9-22]. Available from: http://www.mmspektrum.com/clanek/vyspele-strategie-ve-3d-frezovani.html

[7] Vopat, T[omáš]; Peterka, J[ozef]; Simna, V[ladimír] \& Kuruc, M[arcel] (2014). The Influence of Different Types of Copy Milling on the Surface Roughness and Tool Life of End Mills, Proceedings of the 25th DAAAM International Symposium, pp.0108-0116, B. Katalinic (Ed.), Published by DAAAM International, ISSN 1726-9679, Vienna, Austria

[8] Vopat. T.; Peterka. J.; Kovac. M. \& Buransky (2013). I.:The Wear Measurement Process of Ball Nose End Mill in the Copy Milling Operations. Proceedings of the 24th DAAAM International Symposium, B. Katalinic (Ed.), Published by DAAAM International, ISSN 1726-9679, Vienna, Austria.

[9] Lim, E.M.; Feng, H .Y.; Menq, C.H. \& Z.H. Lin (1995). The prediction of dimensional error for sculptured surface productions using the ball end milling process. Part 1. Chip geometry analysis and cutting force prediction Int. J. Mach. Tools Manufact, 35 (8) (), pp. 1149-1169

[10] Tunc, L[ütfi]; Ozkirimli, O[mer]; Budak, E[rhan] (2015). Machining strategy development and parameter selection in 5-axis milling based on process simulations. The International Journal of Advanced Manufacturing Technology, $1 \neg 18$. Available from: http://link.springer.com/article/10.1007\%2Fs00170 $015 \neg 8001 \neg 6$

[11] Nittler, K[evin] M. \& FaroukiI, R[ida] T. (2016). A real-time surface interpolator methodology for precision CNC machining of swept surfaces. The International Journal of Advanced Manufacturing Technology, 83.1 $\neg 4: 561 \neg 574$. Available from: http://link.springer.com/article/10.1007\%2Fs00170 $015 \neg 7552 \neg x$ 